\title{
EBSP によるアルミニウム缶ボディ材集合組織の観察
} 三菱アルミニウム株式会社技術開発センター 崔祺齊藤洋 大 堀紘一
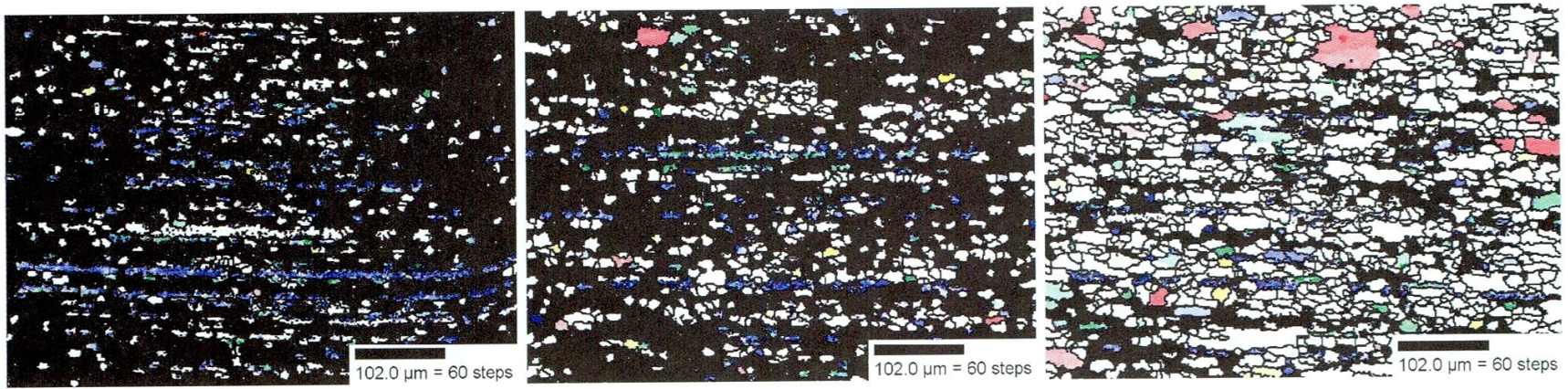

Fig. $1531 \mathrm{~K}$ (左)，538 K (中)， $545 \mathrm{~K}^{\circ}$ (右)で $4 \mathrm{hr}$ 焼鈍した後の結晶粒の方位分布. 赤: Cube 方位, 黄: Cu方 位，青：Brass 万位，緑：S方位，黑い領域：データのない領域，黑い線：15以上の粒界.
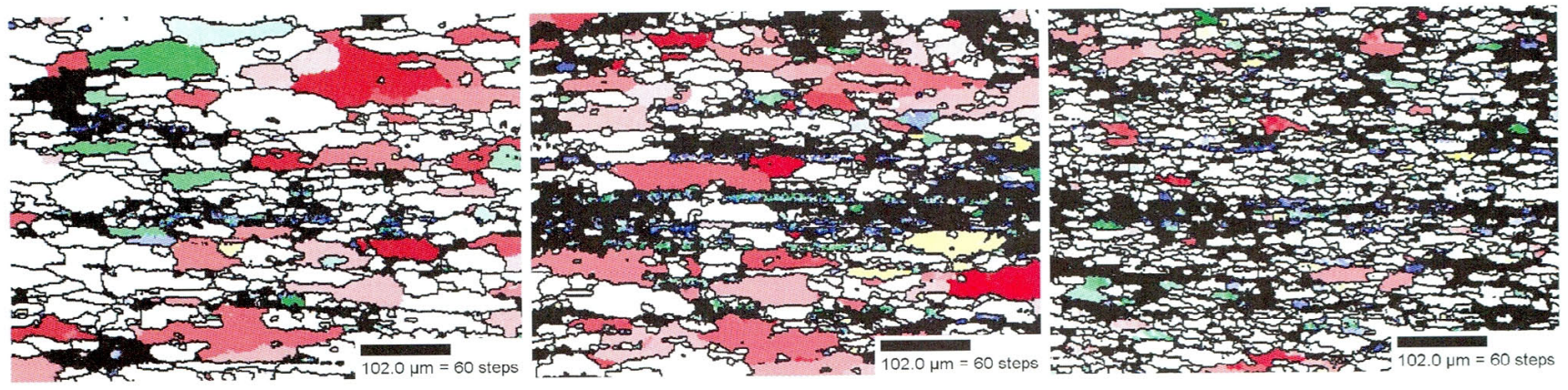

Fig. 2 Fig. 1 に示した試料をそれぞれ11.8\%冷間圧延, 573 K@100 min 焼鈍を追加した後の結晶粒の方位分布. 色 づけはFig. 1 と同じ.

アルミニウム缶ボディは, 通常特硬質の JIS3004 アルミニウム合金冷延板を DI 加工 (Drawing \& Ironing) して成形さ机る. 合金板には, 異方性が低いこと が求められる。一般には，アルミニウム合金圧延板に おいて, $\mathrm{Cu}$ 方位 $\{112\}\langle 111\rangle, \mathrm{S}$ 方位 $\{123\}\langle 634\rangle$, Brass 方位 $\{110\}<112\rangle$ で代表される $\beta$ ファイバ集合 組織が発達する。この場合, DI 成形時に圧延方向か ら約 $45^{\circ}$ 万向に高い耳が生じる。一方，アルミニウム 合金压延板を焼鈍すると，Cube 方位 $\{100\}<001>$ が発 達する．DI成形すると，圧延方向とその $90^{\circ}$ 方向に耳 が生じる。したがって, 目標の圧下率に合わせて Cube 方位を予め適切な強度まで発達させておくと, 冷間圧延後に異方性が低い材料が得られる.

ところが，3004合金において通常の焼鈍では Cube 方位が発達しにくい，通常の焼鈍前に部分焼鈍 +10 ～20\%軽压下冷間圧延を行うと, Cube 方位が発達す る. Fig. 1 に部分燒鈍後の結晶粒方位分布を示寸。 黒い領域は方位データが得られなかった残留ひずみの
高い未再結晶領域である. Fig. 2 に $11.8 \%$ 圧延を追 加した後に通常焼鈍した場合の焼鈍途中の方位分布を 示す，部分焼鈍温度によってCube 方位粒の成長挙動 が異なる。適切な温度 $(538 \mathrm{~K})$ 上り高い場合, Cube 方位粒の優先成長が弱くなり, 通常暁鈍工程に類似す る組織が形成される。一方, 適切な温度より低いと, 他方位粒も成長する。この部分焼鈍温度の調整により Cube 方位の集積度が制御できる。なお, Cube 方位 粒の優先成長は，部分焼鈍時に生じたCube 方位再結 晶粒における軽压下時の残留ひずみが他方位粒より蓄 積されにくいためと考えられる(1).

\section{文献}

(1) 崔 祺, 齊藤 洋, 大堀紘一: 軽金属, 49(1999), 583-
588 .

(2003年 8 月 6 日受理)

EBSP Observation of Texture in Aluminum Can Body Stock; Qi Cui, Hiroshi Saitoh, Koichi Ohori (Mitsubishi Aluminum Co., Susono) Keywords: aluminum alloy, texture, preferred growth EBSP utilized: OIM3.0, SEM utilized: Philips XL30FE (20 kV) 